\title{
BIBECHANA
}

ISSN 2091-0762 (Print), 2382-5340 (Online)

Journal homepage: http://nepjol.info/index.php/BIBECHANA

Publisher: Department of Physics, Mahendra Morang A.M. Campus, TU, Biratnagar, Nepal

\section{Effects of lightning as a disaster in Himalayan region}

\author{
P. B. Adhikari ${ }^{*}$, A. Adhikari ${ }^{2}$ A.K. Tiwari ${ }^{3}$ \\ ${ }^{1}$ Department of Physics, Tri - Chandra M. Campus, Tribhuvan University, Kathmandu, Nepal. \\ ${ }^{2}$ Department of Electronics and Computer Engineering, Pulchowk Campus, Tribhuvan University, \\ Kathmandu, Nepal. \\ ${ }^{3}$ Department of Physics, Patan M. Campus, Tribhuvan University, Kathmandu, Nepal \\ Email: pitribhakta_adhikari@hotmail.com
}

\section{Article Information:}

Received: May 28, 2020

Accepted: May 29, 2021

Keywords:

Disaster in Himalayan region Lightning as a major disaster Awareness program

Lightning hazard

Potentially hazard areas

DOI: https://doi.org/10.3126/bibechana.v18i2.29168

\begin{abstract}
In Nepal, the main disasters are flood, lightning, fire, epidemics, and landslides. Among the several disasters in the Himalayan region, lightning is an important one. Because of the short distance (about $160 \mathrm{~km}$ ) between the low land and peak Mount Everest from South to North, there is a variation of about $95^{\circ} \mathrm{C}$ temperature in these regions. The topographical features of the southern slopes and variation of temperature within this short distance influences the features of lightning and in this scenario, we get positive cloud to ground lightning frequently which is more dangerous for human beings, animals and property. In the Himalayan region, thunderstorms occur near the mountains due to which more positive charge can easily transfer from cloud to ground. Hence positive lightning occurs in the Himalayan region. Majority of the lightning affected people are unaware of lightning safety and they should know the measures to protect life and property from lightning hazards. Hence on conducting awareness program for the people of potentially hazard areas, the number of injured people can be reduced as well as electrical, medical, militarily equipment can be somewhat protected from lightning.
\end{abstract}

This work is licensed under the Creative Commons CC BY-NC License. https://creativecommons.org/licenses/by-nc/4.0/

\section{Introduction}

Nepal is a Himalayan country which lies in the northern hemisphere within the latitude $26^{\circ} 22^{\prime} \mathrm{N}$ to $30^{\circ} 27^{\prime} \mathrm{N}$ and elongated along east west with longitude $80^{\circ} 4^{\prime} \mathrm{E}$ to $88^{\circ} 12^{\prime} \mathrm{E}$. The altitude of the low land is $59 \mathrm{~m}$ in the Terai region to the maximum height of $8848 \mathrm{~m}$, the height of Mount Everest. Another interesting fact about Nepal is the air distance between the low land and the highest mountain of the world Mount Everest, which is about $160 \mathrm{~km}$ due to which there are different environments and climates in different regions. The temperature at the lowlands reaches maximum of about $45^{\circ} \mathrm{C}$ whereas the minimum temperature at the top of Mount Everest is about $-50^{\circ} \mathrm{C}[1,2]$. Hence the temperature difference between the short ranges of about $160 \mathrm{~km}$ is $95^{\circ} \mathrm{C}$ which is the main 
cause of the diversity of weather and climate. This variety of topography within a short distance produces different types of lightning. As we know, water always flows from higher to lower lands and due to the short distance, the flow of water should be high. This scenario can be seen in the east to the west all over the country. Due to this, other disasters such as landslides, floods, etc. can be seen in rainy season frequently which causes loss of human lives and animals along with destruction of physical properties of billions of dollars each year [3].

Nepal is mainly divided into three regions: The Terai lowlands, the Himalayan region in the north with the hilly mountainous region in between. The main disasters in the Terai region are flood in rainy season, fire in dry season, epidemics in summer season and lightning in pre-monsoon period. Similarly, in the mountainous region, epidemics, flood, landslides, forest fires, hailstorms, soil erosion, lightning are the main disasters while in the Himalayan region, glacier lakes outburst, floods, avalanche, etc. are added to this list. According to the Disaster report 2015, it mentioned that earthquake, epidemics and lightning are the main disasters all over the country. The data reported during the period of 48 years is mentioned in the following table below. The data presented in this table consists of the death of people due to epidemics, earthquakes, landslides, flood, lightning and fire which are the main disasters of Nepal in respective order [4].

Lightning is a common natural activity that occurs in the atmosphere. During this process, high energy is released in different forms of energy such as light energy, heat energy, sound energy and other electromagnetic radiations $[5,6]$. The cumulonimbus, the primary source of lightning produces the lightning discharge which is called thunder cloud or thunderstorm. Thunderstorms produce more than 100 lightning flashes within a minute as mentioned by Rakov and Uman (2003), and it can generate power in the order of hundred MegaWatts. They also reported that about 20,000 people are affected by lightning globally and about the same number are injured [7]. Besides these people, many animals are affected by the lightning. Atmospheric structure and hydrometerological process on the south slopes of the Himalayan region in Nepal are not well documented as mentioned by Barros and Lang [8]. The signature of waveform of the lightning electromagnetic field of the mountainous country Nepal are of very much interest to the scientific community of the world. Because of the geological scenario of the mountainous country Nepal, lightning is also taken as one of the largest disasters. The recorded data mentioned in the following tables are not accurately reported as lightning strikes individuals and not to large groups of people, because of which information is scattered and cannot be easily counted [9]. Lightning occurs between two surfaces, either cloud and cloud or cloud and ground or cloud and air. Among them, if the discharge occurs from a charge center of cloud to the charge center of another cloud, it is called intra cloud discharge. If the charge moves from one center to another center within the same cloud, it is called inter cloud discharge. Similarly, if the charge moves from cloud to air it is cloud to air discharge and the discharge that occurs and reaches the ground is called cloud to ground discharge. Hence, the lightning may be categorized mainly into two types:

a) Ground flash

b) Cloud flash

Ground flash is the electrical discharge phenomena between the cloud-to-ground whereas the cloud flash includes the inter-cloud, intra-cloud and cloud to air discharge [10, 11]. Williams et al. reported that there is a tripole charge structure in the thunderstorm cloud, the negative charge which lies at the center of the cloud, an equal amount of positive charge above the negative charge center, which are called main positive and main negative charges, and some positive charge as a pocket charge on the bottom part of the cloud [12]. The diagram of this charge structure is shown in Fig. 1 below. 


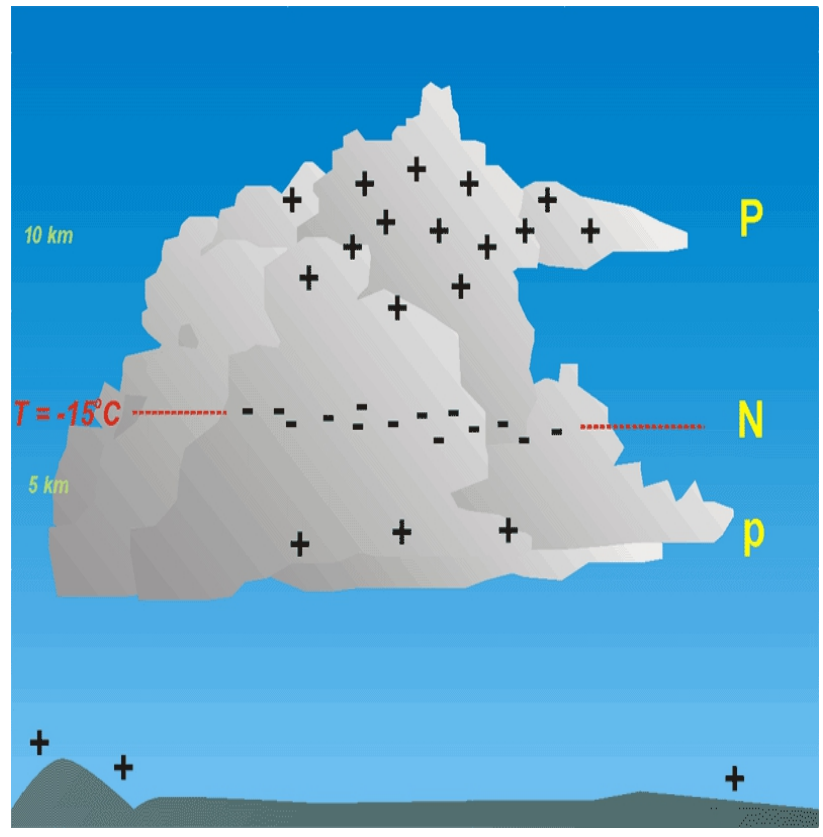

Fig. 1: Tri-pole charge structure of the cloud, Negative at the centre part of the cloud, Positive at the top part of the cloud and some positive charge at the bottom part of the cloud as a pocket charge.

In the cloud to ground discharge, if the positive charge transfers from cloud to ground it is called positive lightning whereas if the negative charge of the cloud transfers to ground, it is called negative lightning. These types of lightning can be seen in Fig. 2 below. The lightning current in the strike reaches a peak value of about $30 \mathrm{kA}$ in average but the maximum current reaches up to $200 \mathrm{kA}$ in negative lightning with the temperature of the stroke during lightning about $30,000 \mathrm{~K}[7,13,14]$. They also reported that the positive lightning is stronger than the negative one due to more charge transfer from cloud to ground occurring in the positive lightning. In this case, the current during the lightning process reaches a maximum of 400 $\mathrm{kA}$. Due to this high current up to $400 \mathrm{kA}$ and the temperature $30,000 \mathrm{~K}$, which is five times the surface temperature of the sun, lightning is considered a major disaster.

Baral and Mackerras reported that in mountainous country Nepal, $28 \%$ of total cloud to ground lightning is positive lightning [15]. Hence in a Himalayan country such as Nepal, lightning is a major disaster which can damage not only lives of human beings and animals but also cause fire on buildings, electrical equipment, etc. Hence, in this paper, the disaster due to the lightning since 2015, is examined and it has been clearly noticed that the lightning affects human life, animals, buildings, electrical equipment, electrical lines, telecommunication lines, etc. in the Himalayan region.

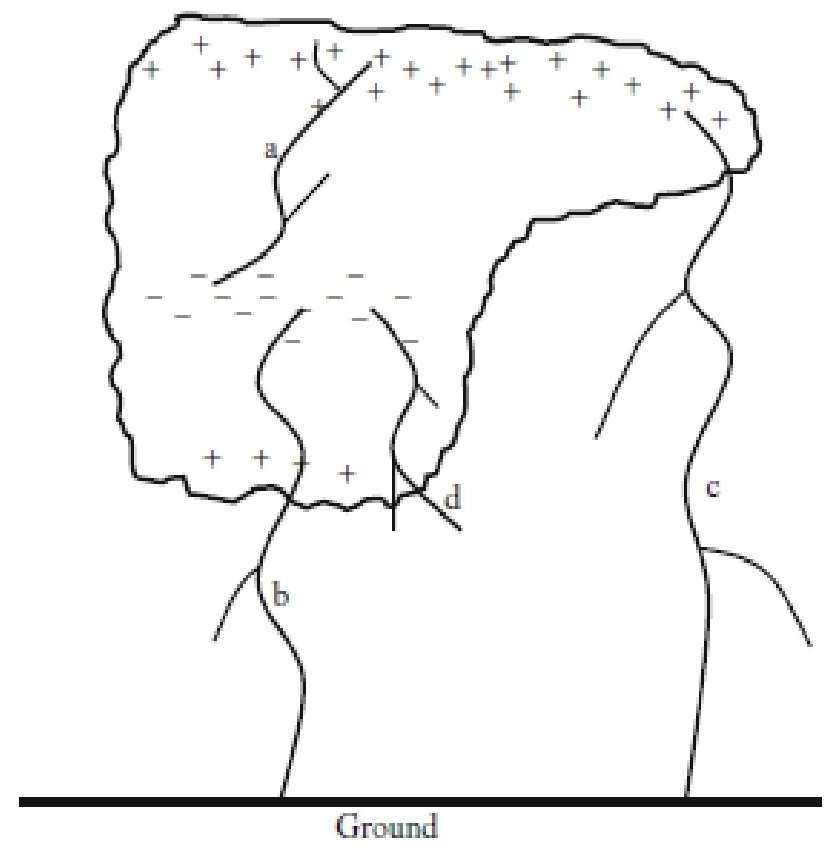

Fig. 2: Different types of the cloud, a represents intra-cloud lightning, b represents negative Cloud to ground lightning, c represents positive Cloud to ground lightning and $\mathrm{d}$ represents Cloud to air discharge.

\section{Instrumentation and Methodology}

In the phenomena of lightning discharge, there are electromagnetic radiations of different wavelengths and frequencies. These radiations travel in all possible directions from discharge channel. These vertical electric field is captured by the horizontal parallel plate antenna [16]. The waveforms were sensed by the antenna fixed on a $1.5 \mathrm{~m}$ high post 
which is shown in the Fig. 3 below. This antenna is placed on the rooftop of a building at height $12 \mathrm{~m}$ above from ground. The signal given by the antenna passing through buffer circuit, which is shown in the Fig. 4 below, and is connected to the Pico-scope 6404D through a $20 \mathrm{~m}$ long RG 58 coaxial cable. The diagram of the Picoscope 6404D is shown in the Fig. 5. There are mainly positive lightning events, unusual lightning events and cloud events of different flashes recorded from the Himalayan region. The electronic circuit which was used in present work for the Himalayan region was also used by other several researchers [17-21].

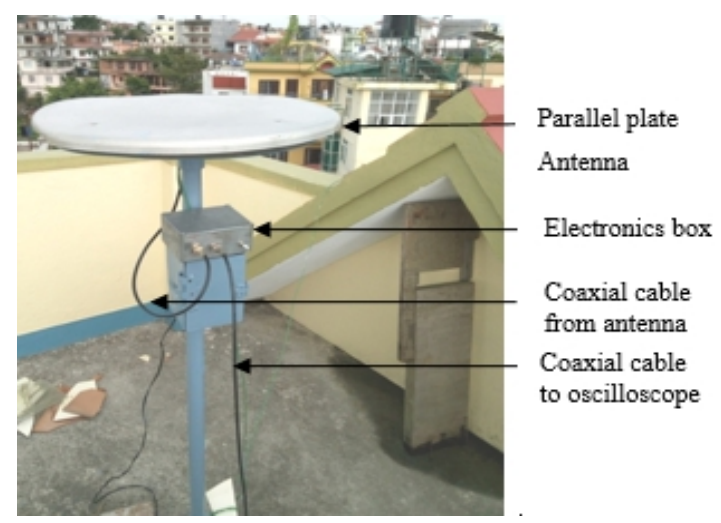

Fig. 3: The elevated parallel-plate antenna installed in Kathmandu.

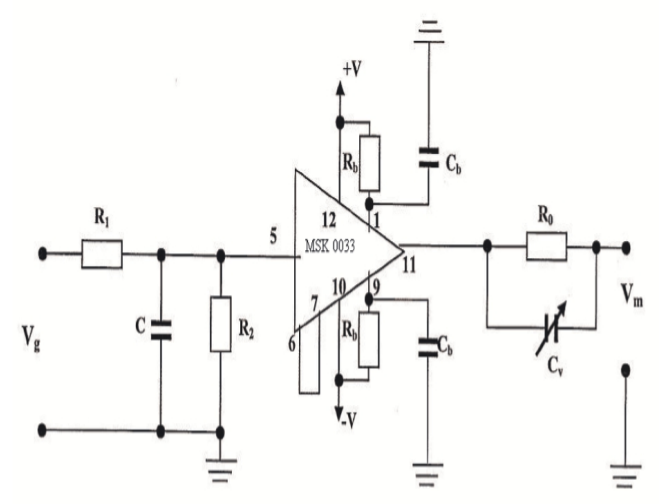

Fig. 4: The electronic circuit inside the buffer amplifier.

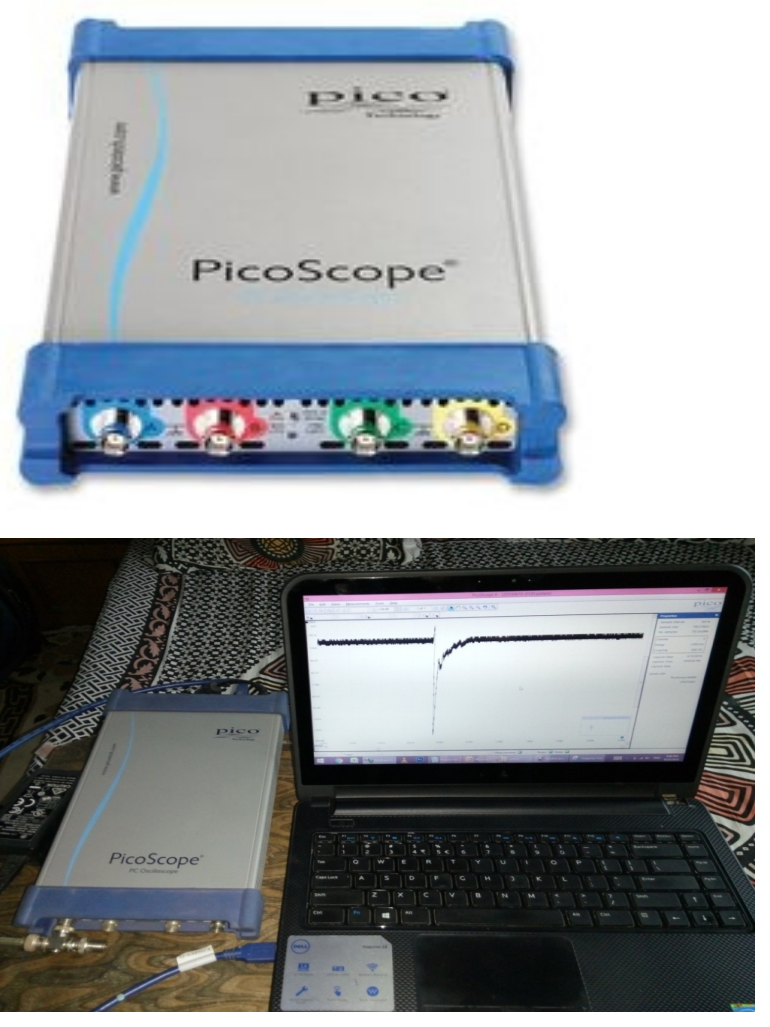

Fig. 5: The diagram of the Picoscope 6404D and is connected through RG 58 co-axial cable.

\section{Observation and Discussion}

Nepal is one of the highest risk countries in the world because of its geographical structure in the context of lightning. The northern part of Nepal is covered by the high Himalayas and the lower southern part consists of plain Terai lands and in between are the rugged mountainous region with steep slopes. Due to this geographical structure, disasters such as landslides, floods, thunderstorms, thunderbolts, etc. occur very frequently. Landslide is the main disaster among these. In the Terai region, the main disaster is fire as this region has vast jungles and animal terror is also very common. Many people lose their lives as a direct result of natural as well as human induced incidents. There is a great challenge to protect the people, animals and property in the structures from these disasters. The scenario of the incidents along with the data of casualties, lost property and affected families is shown in Table 1 below. 
Table 1: Multi hazard scenario of Himalayan region, Nepal in 1978 -2018*

\begin{tabular}{|c|c|c|c|c|c|c|}
\hline \multirow{2}{*}{$\begin{array}{l}\text { Types of } \\
\text { Disaster }\end{array}$} & \multirow{2}{*}{$\begin{array}{l}\text { Number of } \\
\text { Incidents }\end{array}$} & \multicolumn{4}{|c|}{ Human Loss } & \multirow{2}{*}{$\begin{array}{c}\text { Houses } \\
\text { Damaged }\end{array}$} \\
\hline & & Death & Missing & Injured & Affected Family & \\
\hline Fire & 12694 & 1755 & & 2176 & 265962 & 90044 \\
\hline Lightning & 2143 & 1780 & 129 & 3235 & 7758 & 1000 \\
\hline Landslide & 3729 & 5141 & 191 & 2053 & 559347 & 34094 \\
\hline Windstorm & 298 & 21 & & 95 & 1718 & 1279 \\
\hline Flood & 4368 & 4628 & 87 & 615 & 3726261 & 230900 \\
\hline Epidemics & 3574 & 16598 & & 44992 & 513409 & 0 \\
\hline Avalanche & 3 & 17 & 4 & 7 & 1 & 0 \\
\hline Snow Storm & 7 & 97 & 7 & 0 & 10 & 0 \\
\hline Hailstones & 134 & 9 & & 24 & 3407 & 157 \\
\hline Earthquake & 175 & 9771 & & 29142 & 890995 & 982855 \\
\hline Cold Waves & 438 & 563 & & 83 & 2441 & 0 \\
\hline Others** & 1134 & 626 & 13 & 919 & 3214 & 2461 \\
\hline Total & 28597 & 41006 & 431 & 83341 & 5974523 & 1342790 \\
\hline
\end{tabular}

*National Emergency Operation Center, Ministry of Home Affairs (NEOC, MoHA)

**Structure collapse, drowning, boat capsize, animal attack, Snake bite and others.

As the report given in National Emergency Operation Center, Ministry of Home Affairs (NEOC, MOHA), the multi hazard scenario of Nepal by its socio-economic loss during the period of 1971 to 2018, i.e. in 48 years' period, landslide, flood, epidemic, earthquake, lightning and fire are the main disasters of Nepal. In this period, more than 41,000 people lost their lives in the 28,597 incidents of these disasters and 83,341 people were injured. 431 people were missing and 5,974,523 families were affected altogether with $1,342,790$ houses being damaged. These scenarios are presented in Table 1, which represents the incidents on human beings only but the effects on animals and other beings are not shown. NEOC, MOHA published a report that during the two years 2017 and 2018 only, the estimated loss of NPR $6,838,828,320$ occurred which is very high in the context of Nepal. During this period, 968 people died, 3639 people were injured and 27,255 families were affected by disasters. These numbers are quite high even when no major earthquakes occurred but 4433 houses were completely destroyed whereas 16308 houses were partially destroyed. These data are presented in Table 2 below and the bar diagram of these disaster data are represented in Fig. 6. Since the number of casualties due to epidemics is very high, it is not presented in the bar diagram because of scaling issues. 
Table 2: Damages and losses of Disaster Incidents in 2017 and 2018

\begin{tabular}{|c|c|c|c|c|c|c|c|}
\hline \multirow[t]{2}{*}{ Disasters } & \multirow{2}{*}{$\begin{array}{c}\text { No. of } \\
\text { Incidents }\end{array}$} & \multirow[t]{2}{*}{ Death } & \multirow[t]{2}{*}{ Injured } & \multirow{2}{*}{$\begin{array}{c}\text { Affected } \\
\text { Family }\end{array}$} & \multicolumn{2}{|c|}{ Houses Distroyed } & \multirow{2}{*}{$\begin{array}{c}\text { Estimated } \\
\text { Loss (NPR) }\end{array}$} \\
\hline & & & & & Partial & Complete & \\
\hline Flood & 418 & 183 & 61 & 16196 & 14424 & 286 & $60,944,400$ \\
\hline Lightning & 432 & 160 & 551 & 618 & 23 & 14 & $14,687,000$ \\
\hline Landslide & 483 & 161 & 182 & 1083 & 149 & 328 & $191,662,000$ \\
\hline Fire & 3973 & 150 & 557 & 6027 & 549 & 3234 & $6,422,638,013$ \\
\hline Windstorm & 254 & 19 & 84 & 1527 & 763 & 301 & $51,447,998$ \\
\hline Heavy Rainfall & 342 & 30 & 84 & 538 & 193 & 252 & $89,415,160$ \\
\hline Animal Terror & 141 & 22 & 69 & 280 & 136 & 8 & $4,390,150$ \\
\hline Epidemics & 22 & 15 & 1881 & 420 & 0 & 0 & - \\
\hline High Altitude & 45 & 41 & 6 & 46 & 0 & 0 & - \\
\hline Boat Capsize & 10 & 16 & 9 & 27 & 0 & 0 & - \\
\hline Snake Bite & 18 & 14 & 5 & 18 & 0 & 0 & - \\
\hline Snow Storm & 2 & 10 & 0 & 10 & 0 & 0 & - \\
\hline Hailstones & 3 & 0 & 0 & 127 & 2 & 0 & 457,000 \\
\hline Cold Waves & 48 & 48 & 0 & 48 & 0 & 0 & - \\
\hline Others** & 189 & 99 & 150 & 289 & 69 & 10 & $3,181,599$ \\
\hline Total & 6381 & 968 & 3639 & 27255 & 16308 & 4433 & $6,838,823,320$ \\
\hline
\end{tabular}

*- Source: National Emergency Operation Center, Ministry of Home Affairs (NEOC, MoHA)

** - Structure collapse, drowning, Avalanche and others.

Among the various disasters of Nepal, lightning is a dangerous one not only because of the loss of lives but also to animals, fires in jungle and incident of injuries to living beings, buildings and electrical equipment. Nowadays, lightning unknowingly damages various equipment such as television, radio, refrigerator, computer, phone and other electrical components. Due to high voltage of lightning, it damages buildings and electrical components. It may cause fire in a building as well. We have observed and recorded the waveforms produced by lightning through the instrument PicoScope 6404D in Himalayan region of Nepal measured from Kathmandu, Nepal. Some of the examples of waveforms observed in the Himalayan region recorded from Kathmandu are presented in the following Figs. (7-9). As we know, Nepal has the variation of altitude from about $59 \mathrm{~m}$ to $8848 \mathrm{~m}$ within the air distance of $160 \mathrm{~km}$ in the cloud which can be seen near the mountains as shown in Fig. 10 below. There are various types of lightning are mentioned already, but cloud to ground lightning and cloud to cloud lightning are common. In Nepal, we often get unusual lightning activities of unique type and cloud to ground lightning also occurs frequently because of which lightning is more dangerous in Nepal. An example of the unusual type of lightning is shown in Fig. 7 and one example of positive cloud to ground lightning is presented in Fig. 8 below. Generally, in positive lightning, the stroke occurs without the stepped leaders but here in the Himalayan region, we observed and recorded the stepped leaders with the stroke [22]. The example of the stepped leader with the stroke is shown in the Fig. 9. 


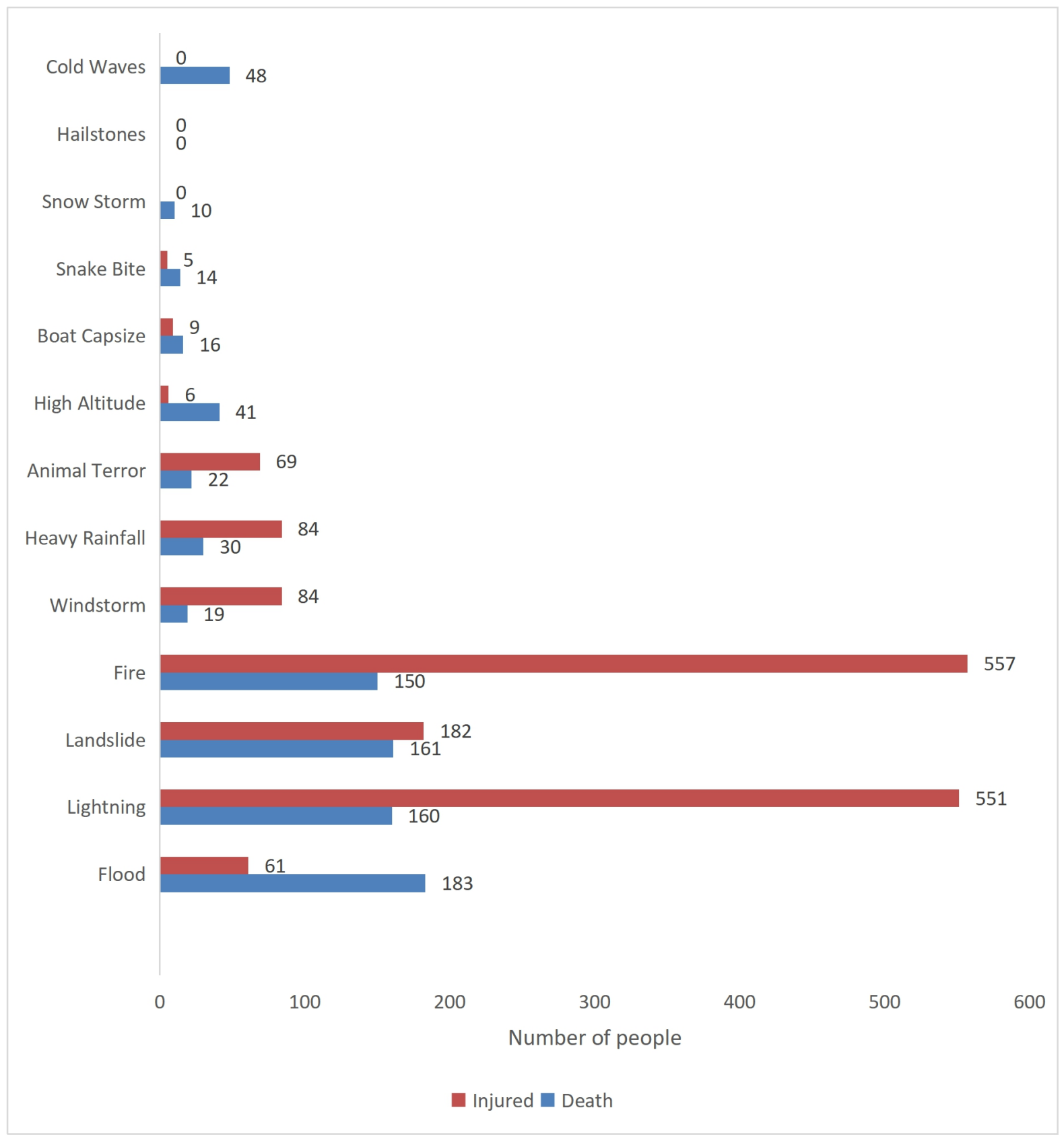

Fig. 6: The diagram of

the data of number of people injured and death due to disaster incidents in 2017 and 2018.

As already mentioned, that lightning is one of the major disasters of Nepal, we found that more than 100 people lost their lives in each year and more than 300 people were injured annually with more than 6 million NPR being lost. The data is presented in the following table 3 , in which the casualty of the human lives and human injured are mentioned since 2015AD. 


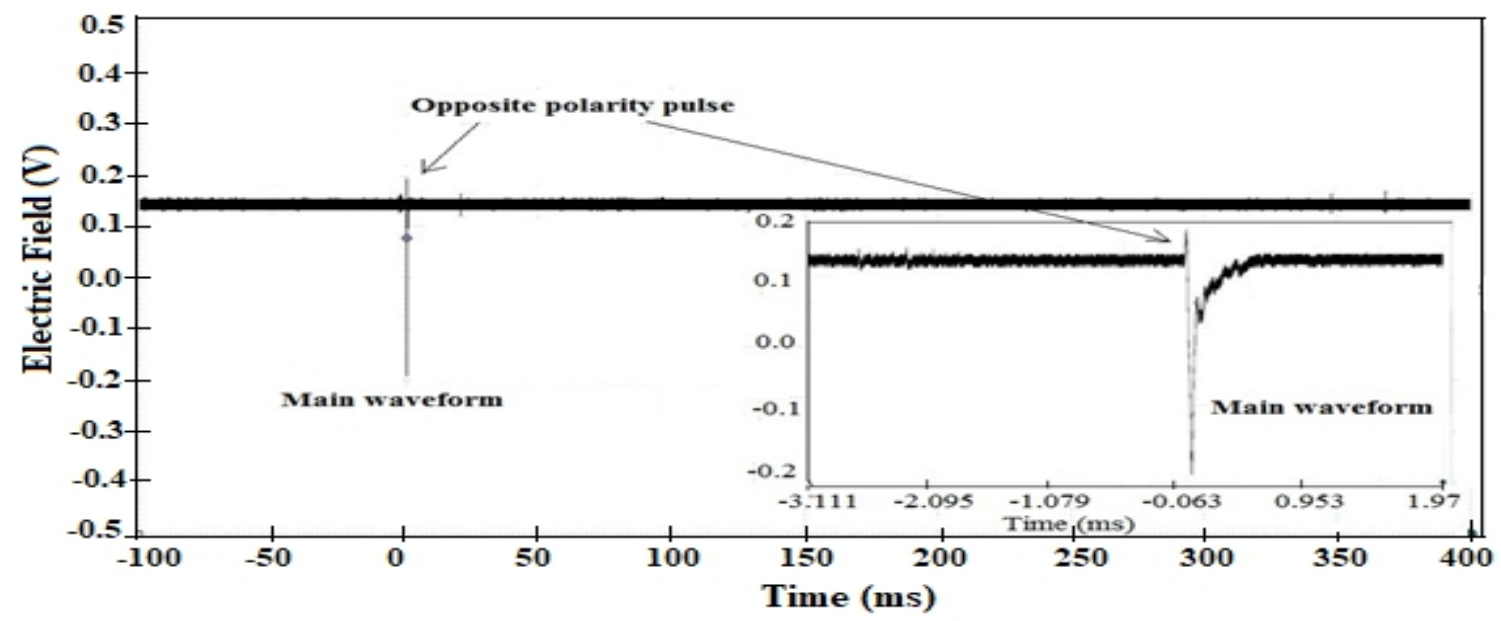

Fig. 7: One example of the unusual waveform and expanded the waveform is presented in incent [23].

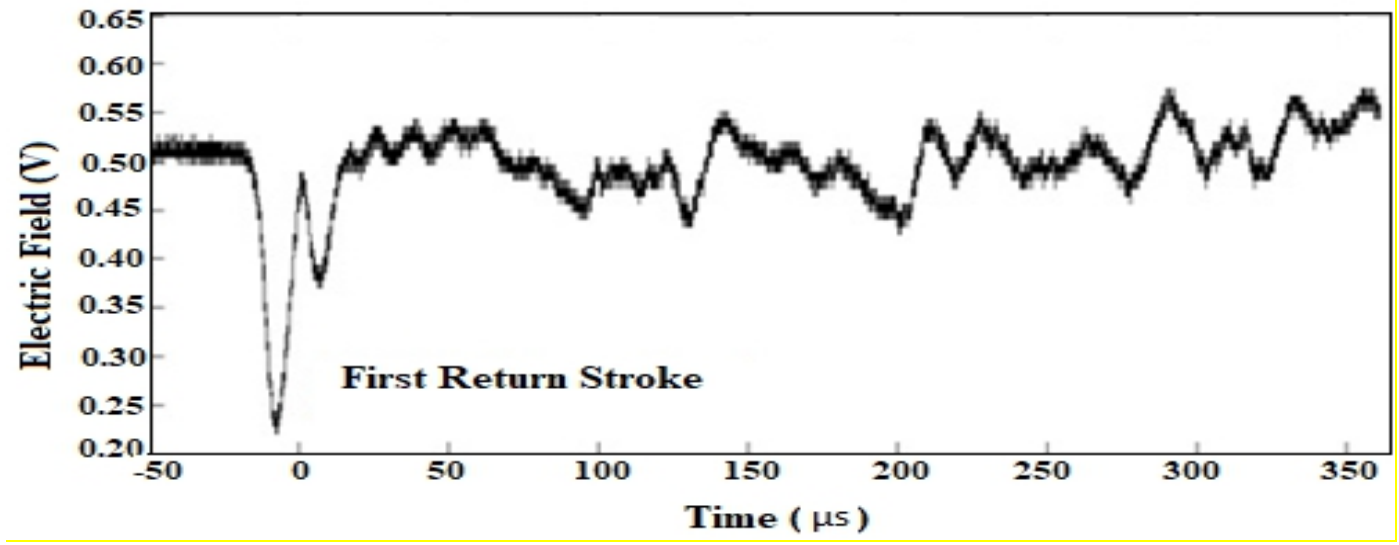

Fig. 8: One example of the positive lightning waveform recorded in the Himalayan region.

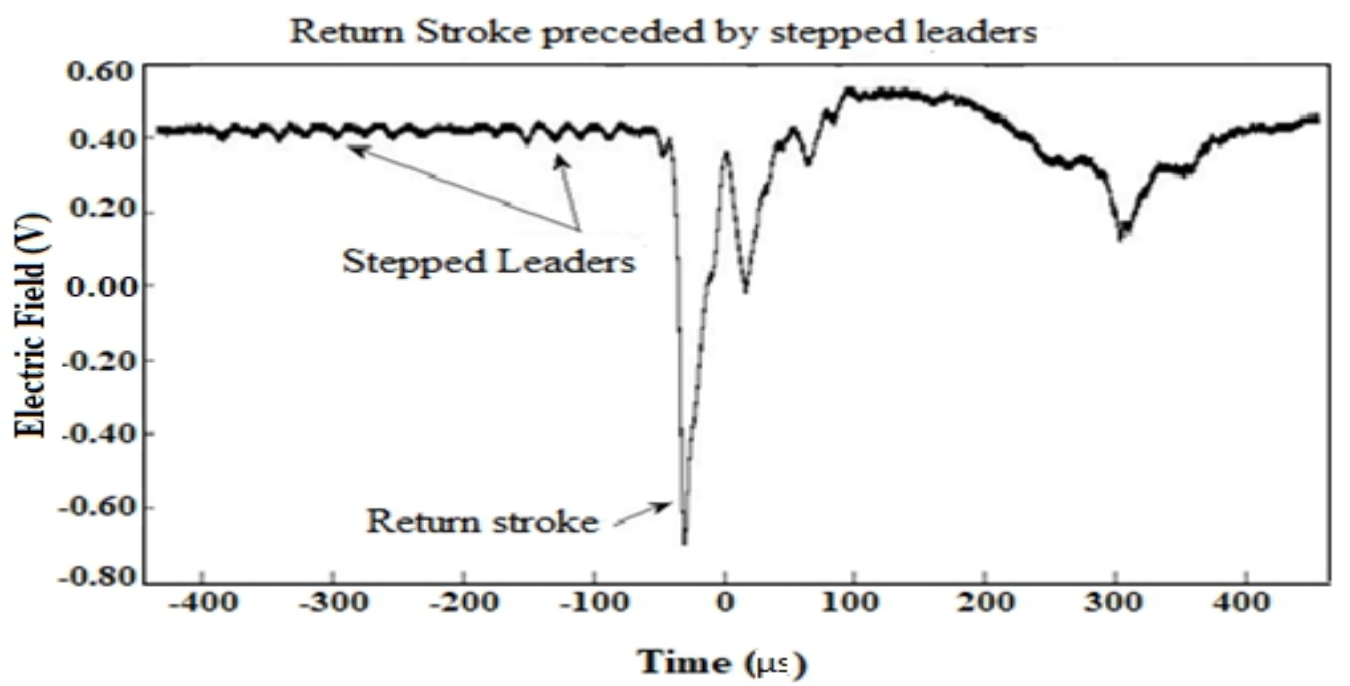

Fig. 9: One example of the positive lightning of return stroke waveform with the stepped leaders recorded in the Himalayan region [24]. 


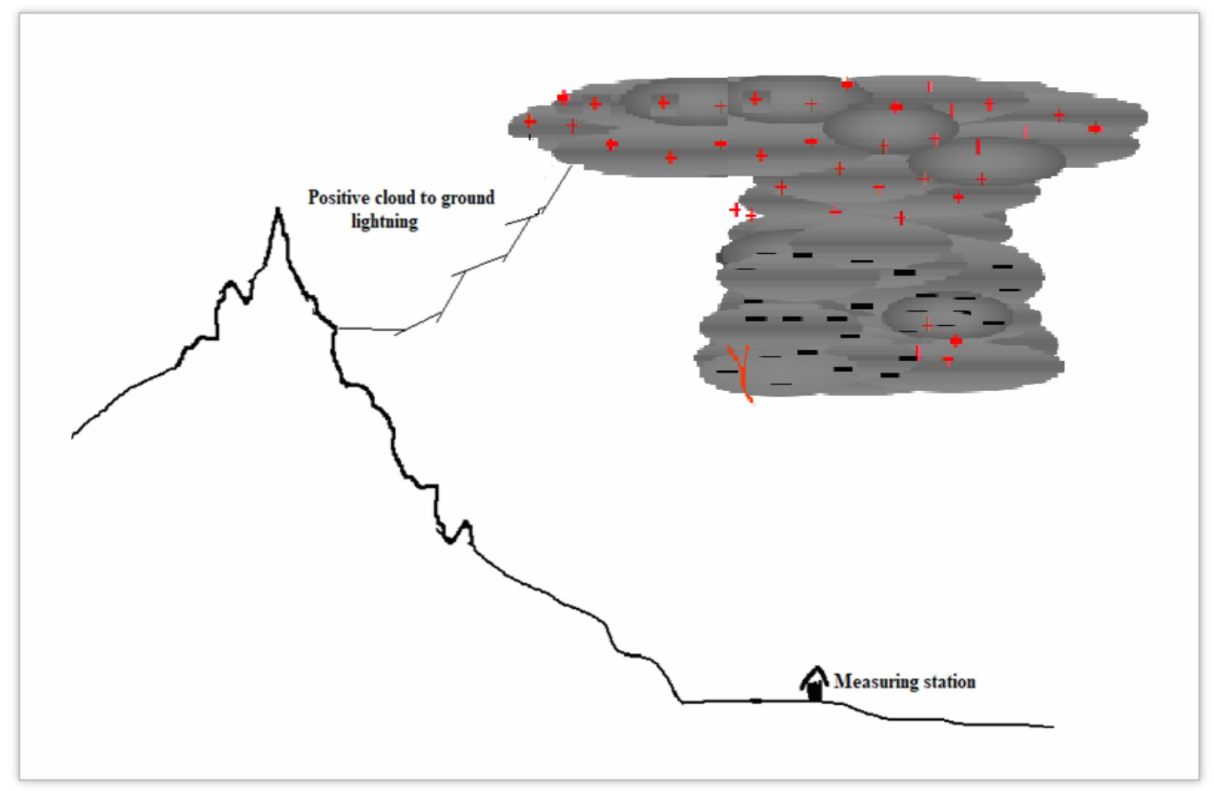

Fig. 10: The example of the cloud of tripole charge structure just near the mountain and the positive lightning occurs frequently due to the shorter distances

Table 3: The data recorded due to Lightning in the Himalayan Region as a Disaster

\begin{tabular}{|c|c|c|c|c|c|}
\hline Year & $\begin{array}{c}\text { Death of the } \\
\text { People }\end{array}$ & $\begin{array}{c}\text { No. of } \\
\text { Incidents }\end{array}$ & $\begin{array}{c}\text { No. of Injured } \\
\text { People }\end{array}$ & $\begin{array}{c}\text { Total estimated Cost } \\
\text { Rs }\end{array}$ & $\begin{array}{c}\text { Affected } \\
\text { Family }\end{array}$ \\
\hline $\mathbf{2 0 1 5}$ & 103 & 148 & 187 & 1000000 & 60 \\
\hline $\mathbf{2 0 1 6}$ & 118 & 206 & 240 & 3321000 & 259 \\
\hline $\mathbf{2 0 1 7}$ & 85 & 188 & 251 & 9125000 & 258 \\
\hline $\mathbf{2 0 1 8}$ & 75 & 244 & 300 & 5562000 & 360 \\
\hline $\mathbf{2 0 1 9}$ & 94 & 383 & 451 & 12208000 & 529 \\
\hline $\mathbf{2 0 2 0} *$ & 34 & 173 & 191 & 6931500 & 392 \\
\hline Total & 509 & 1342 & 1620 & 38147500 & 1858 \\
\hline
\end{tabular}

*- Up to May 15.

\section{Effect of Lighting}

There are many impacts of lightning including human casualties and death of animals, the secondary major impacts and effects are on power and tele-communication lines. Lightning is not only the death of the people but also its hazardous effects. If there is direct strike of lightning to a person or animal, it causes death but besides the direct strike there may be death or injury depending upon the various factors such as striking distance, magnitudes of the current, step potential etc. People are prone to effects of lightning when they take shelter under tall trees and also in open agricultural fields [25]. The data of the death of the people, injured people etc. are presented here in table 3 and some examples of hazardous effect are shown in Fig. 11. The effects of lightning in animals are ten times more dangerous than that of human beings due to step potential and the current flowing inside 
the body through the main organs. We can see just the examples of Jajarkoat on $2^{\text {nd }}$ September, 2019 that 233 sheep were killed and 252 sheep were lost due to a single lightning stroke reported by the Himalayan Times daily Newspaper published on $3^{\text {rd }}$ September, 2019. Similarly, 250 sheep in Sudi village of Tila Rural Municipality-6 in Jumla district were killed due to lightning of single stroke just 3 days before on $29^{\text {th }}$ August, 2019, while in the adjacent mountainous region of Himachal Pradesh in India, more than 200 met the same fate on August $29^{\text {th }}$. This scenario of that event is also presented in Fig. 12 below. They also reported that snowfalls and lightning have been causing a huge loss to the sheep farmers for the past few years. In winter last year, hundreds of sheep were killed due to heavy snowfall.
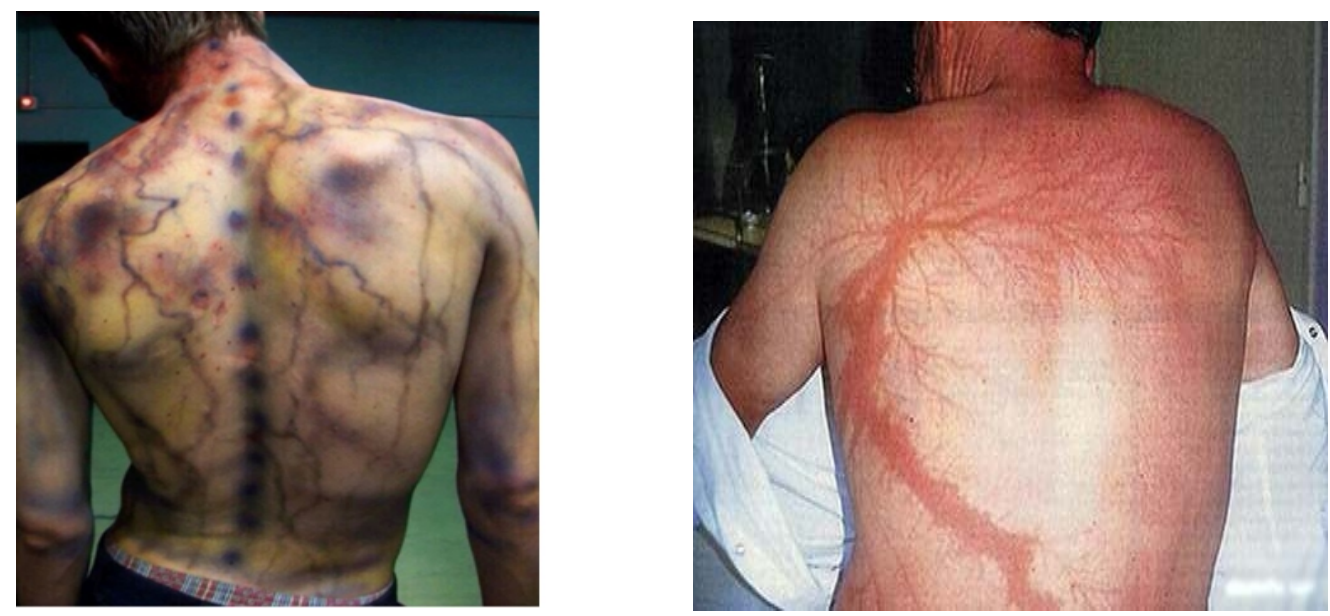

Fig. 11: Some examples of Hazardous effects in the lightning.

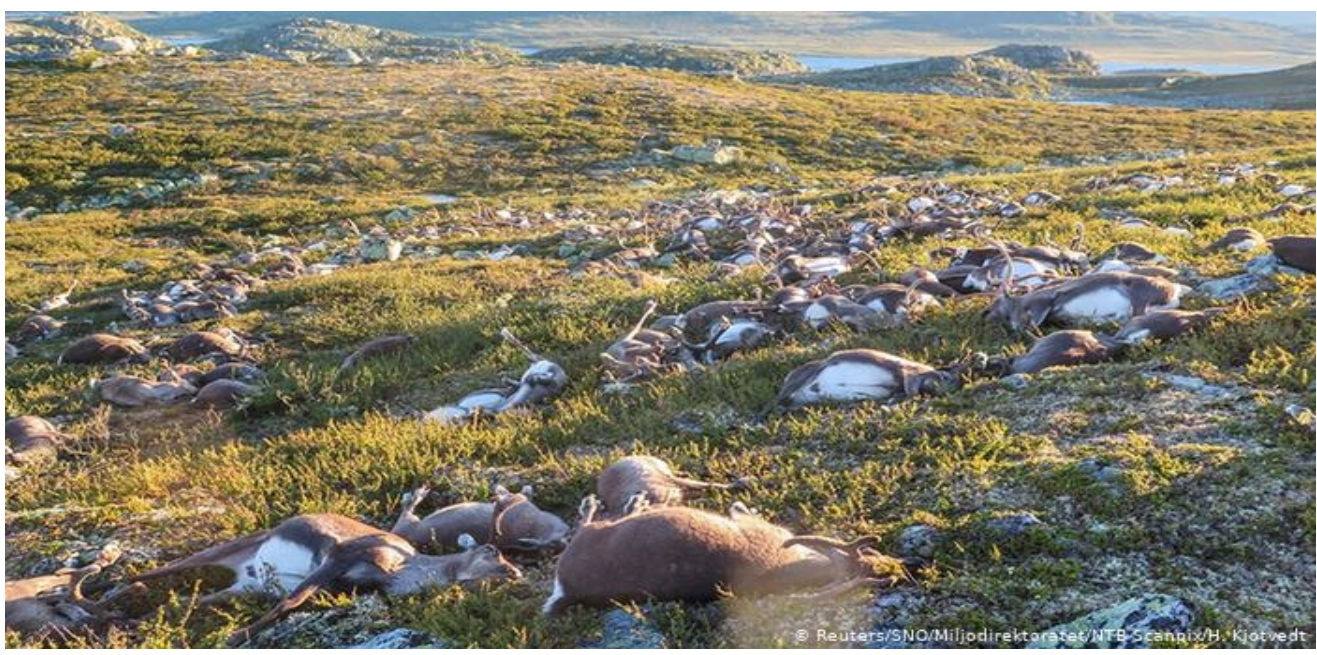

Fig. 12: The example of the loss of animals due to the single lightning stroke in the Himalayan Region. 


\section{Results and Conclusions}

Most important effect of lightning is the human casualties. It ignites fire on the buildings which converts them into ashes. The lightning current which is very high may destroy electrical, electronic and communication equipment beyond repair. The secondary effects of lightning are not only identified as to cause or mechanism. The sophisticated parts of electronic equipment, military equipment, medical equipment, such as MRI, ECG equipment etc. can be destroyed by electromagnetic radiation produced due to lightning. Similarly, the electrical power line and communication lines get affected by the radiation due to lightning. The main scope of the study is to conduct awareness program to the general people to spread the information to protect their life, electrical equipment, etc. The lightning hazard map for the stakeholders is to make plan to protect from lightning activities in the potential hazard areas, and for researchers and scientists to continue further research about lightning activities with various factors. Mitigation of lightning hazards in the Himalayan region is primarily based on the awareness program conducted to the general public and students of school level as well as higher level. Even though awareness program conducted about the lightning mitigates the effects and aware people, the number of victims due to lightning strike has considerably increased throughout the years, which can be seen from the table 3. The bar diagram of the number of injured people and number of deaths since 2015 AD are presented in Fig. 13.

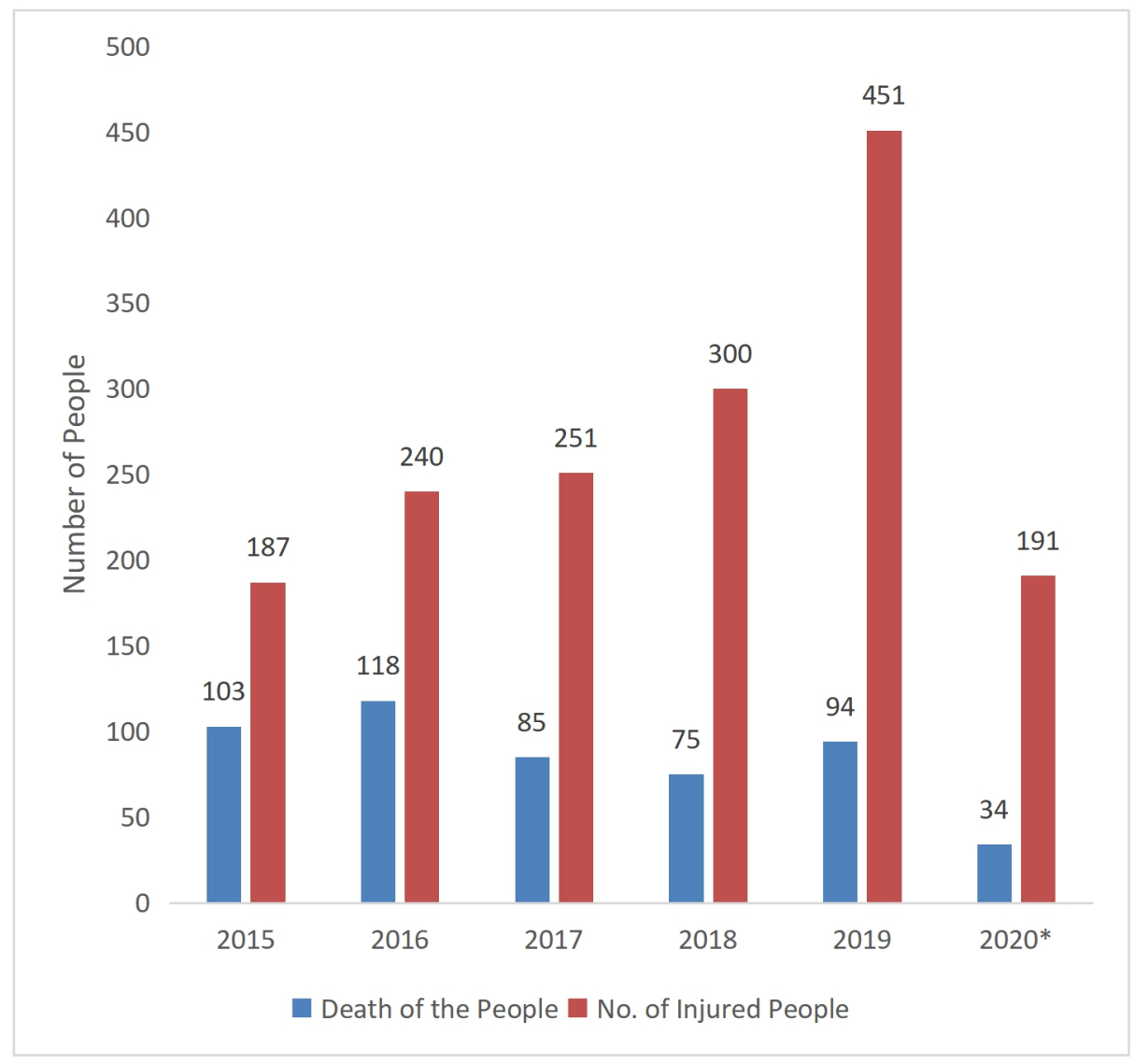

Fig. 13: The bar diagram of the data of number of injured and death of people due to lightning disaster since 2015 . 
From the above bar diagram, it can be concluded that the number of injuries caused to people is far more than the number of deaths. The ratio of injured people to dead people is also increasing which can be seen in the same diagram. The lightning hazards frequently occurred and the areas of potential hazards are presented in the map of the country given in Fig. 14. This information can be used for the preventive purpose to protect from this hazards and to avoid damages to their properties in such areas. This information also can be used in awareness program for the people of hazards area and give suitable instructions to prevent the after effects of lightning.

\section{Lightning Fatalities in Nepal}

\section{Between 13 April 2012 - 11 April 2019}

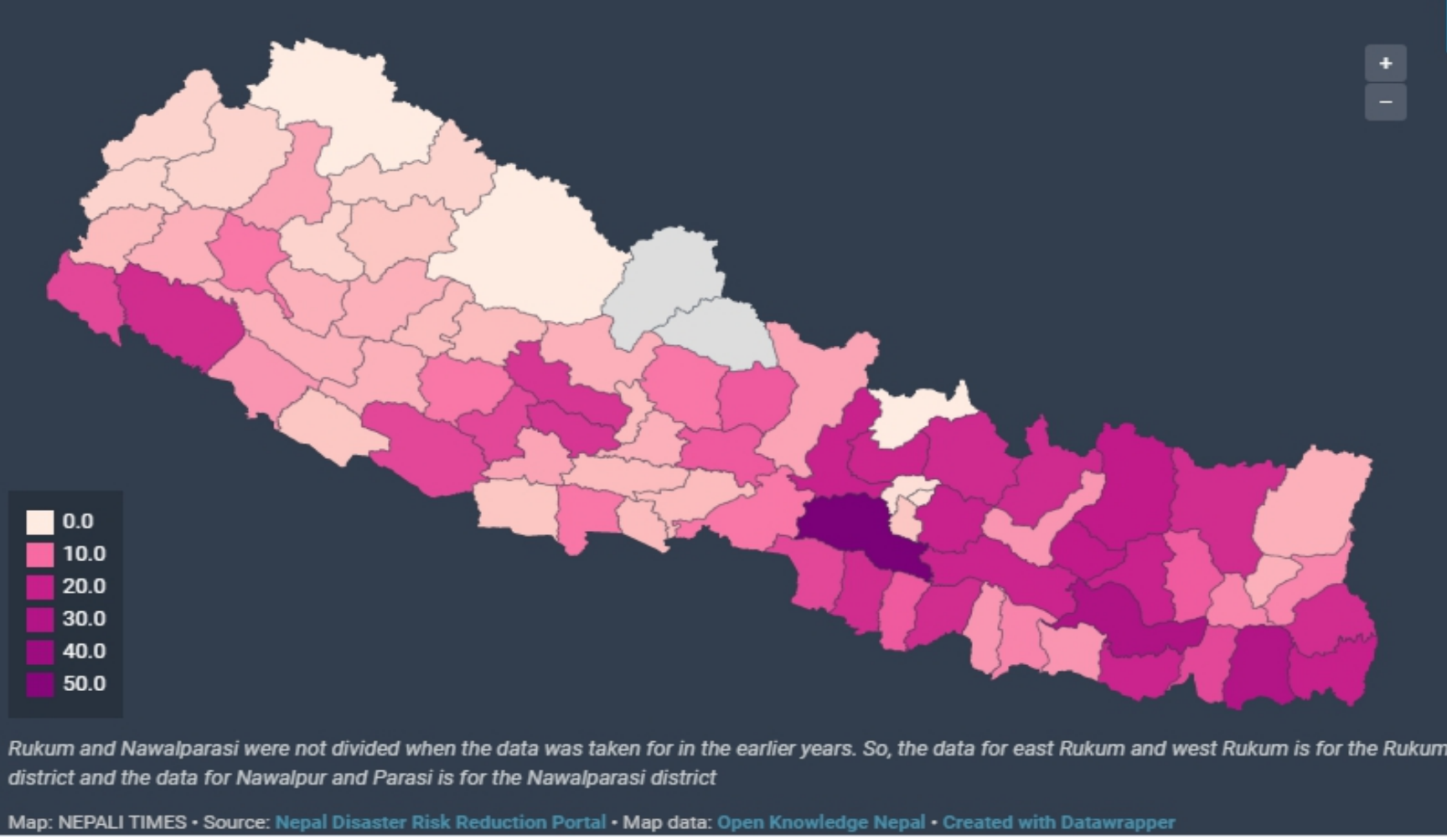

Fig. 14: The fatalities due to lightning represented from 13 April 2012 to 11 April 2019 [Adopted from Nepal Disaster Risk Reduction Portal].

\section{Acknowledgement}

We would like to thank for providing the instruments necessary for this research to the International Science Program (ISP), Uppsala University, Sweden. We would like to express our sincere gratitude to the University Grants Commission (UGC) Sanothimi, Bhaktapur, Nepal, for SDI research Grant of Number- "SRDI - 75/76
- S \& T - 8". We would like to thank the TriChandra College, Tribhuvan University also.

\section{References}

[1] 'P. B. Adhikari, Variation of Atmospheric Temperature with Height in the Phenomena of Lightning Waveforms, World J. Ap. Phys. 4 (2019) 46.

https://doi.org/10.11648/j.wjap.20190404.11. 
[2] T. Wu, D. Wang, and N. Takagi, Intra-cloud lightning flashes initiated at high altitudes and dominated by downward positive leaders, Journal of Geophysical Research: Atmospheres 124 (13) (2019) 6982-98. https://doi.org/10.1029/2018JD029907

[3] Nepal Disaster Report, National Emergency Operation Center, Ministry of Home Affairs, Government of Nepal (2019).

[4] Nepal Disaster Report, National Emergency Operation Center, Ministry of Home Affairs, Government of Nepal (2015).

[5] D. J. Malan, Physics of Lightning. English Universities Press Ltd (1963).

[6] D. R. MacGorman, and W. D. Rust, The Electrical Nature of Storms, New York: Oxford Univeristy Press (1998).

[7] V. A. Rakov, and M. A. Uman, Lightning: Physics and Effects, Cambridge University Press, UK (2003).

[8] A. Barros, and T. Lang, Monitoring the monsoon in the Himalayas: Observation in central Nepal, June 2001, Monthly Weather Review 131 (2003) 14081427.

[9] C. Gomes, Lightning, Hazard Profiles of Sri Lanka, (2013) pp. 104-23.

[10] K. Berger, The Earth Flash. In Lightning, Physics of Lightning, Academic Press, New York (1977).

[11] P. R. Krehbiel, The electrical structure of thunderstorm, the earth's electrical environment, National Academy Press, Washington D. C. (1986).

[12] E. Williams, The tri-pole structure of thunderstorms, Journal of Geophysical Research 94 (1989) 1315167.

[13] M. A. Uman, The Lightning Discharge, Dover Edition, New York (2001).

[14] V. Cooray, An Introduction to Lightning, Springer Netherlands (2015).

[15] K. Baral, and D. Mackerras, Positive cloud-toground lightning discharges in Kathmandu Thunderstorms, Journal of Geophysical Research, 98 (1993) 10331-10340.

[16] P. B. Adhikari, Measurement of Electric Fields due to Lightning Radiation, Springer Nature
Switzerland AG, AISC 905 (2020) pp. 38 - 43. https://doi.org/10.1007/978-3-030-14680-1_5

[17] P. B. Adhikari, and S. R. Sharma, Characteristic features of electric fields radiated by cloud flashes in Himalayan region. International Journal of Antennas and propagation, (2020). https://doi.org/10.1155/2020/6187635.

[18] D. Johari, V. Cooray, M. Rahman, P. Hettiarachchi, and M. Ismail, Characteristics of leader pulses in positive ground flashes in Sweden, Electric Power System Research 153 (2017) 3-9. https://dx.doi.org/10.1016/j.epsr.2016.11.026

[19] P.B. Adhikari, Features of ground flashes before and after the massive earthquake observed from Kathmandu, Nepal, Journal of Nepal Physical Society 4( 1) (2017) 11-22

[20] S. Sharma, Electromagnetic Fields Radiated by Lightning in Tropical and Temperate Regions, $\mathrm{PhD}$ thesis, Faculty of Science, University of Colombo, Sri Lanka (2007).

[21] A. Galvan, and M. Fernando, Operative Characteristics of a Parallel-Plate Antenna to Measure Vertical Electric Fields from Lightning Flashes, Institute for High Voltage, Uppsala University, Sweden (2000).

[22] P. B. Adhikari, S. R. Sharma and K. N. Baral, Features of positive ground flashes observed in Kathmandu Nepal, Journal of Atmospheric and Solar-Terrestrial Physics 145 (2016) 106-113. https://dx.doi.org/10.1016/j.jastp.2016.04016

[23] P. B. Adhikari, S.R. Sharma, K. N. Baral, and V. A. Rakov, Unusual lightning electric field waveforms observed in Kathmandu, Nepal, and Uppsala, Sweden, Journal of Atmospheric and SolarTerrestrial Physics 164 (2017) 172-184. https://dx.doi.org/10.1016/j.jastp.2017.08.028

[24] P. B. Adhikari,, Investigation of the Features of Electromagnetic Fields due to Lightning Measured in Kathmandu, $\mathrm{PhD}$ thesis, Tribhuvan University, Kathmandu, Nepal (2019 b).

[25] C. Gomes, M. Ahmed, F. Hussain, and K. R. Abeysinghe, Lightning Accidents and Awareness in South Asia: Experience in Sri Lanka and Bangladesh, $28^{\text {th }}$ International Conference on Lightning Protection, ICLP (2006). 